Anti-cN1A antibodies were more prevalent in myositis/SS+ patients (33\% vs $5.8 \%, p=0.0032)$. However, in myositis/SS+ group, anti-cN1A were frequent in each of the EULAR/ACR 2017 myositis subtypes and the association between SS and anti-cN1A positivity was maintained in a multivariate analysis adjusted with the diagnosis of IBM $(p=0.023)$

Seven of the myositis/SS+ patients $(22 \%)$ had systemic involvement typical of SS (vs 6 [9\%] of the myositis/SS- patients, $p=0.12$ ) including polyneuropathy (6 [20\%] vs $6[10 \%]$ ) and type 2 cryoglobulinaemic vasculitis (1 [3\%] vs 1 [1.6\%]). In addition, $2(6 \%)$ myositis/SS+ patients developed a lymphoma (one B diffuse large cell lymphoma of the parotid and one non-Hodgkin lymphoma), vs none of the myositis/SS- patients $(p=0.11)$. Only one $(3 \%)$ of the myositis/SS+ patients developed myositis-associated cancer (diagnosed within 3 years of myositis diagnosis) versus $6(9 \%)$ of the myositis/SS- patients $(p=0.66)$.

Aside hydroxychloroquine, more frequently used in myositis/SS+ group (38\% vs $16 \%, p=0.018$ ), no significant difference was found in the management of the patients (taking into account the myositis subtype).

Conclusion: Myositis patients with SS have more frequently IBM than myositis patients without SS. They also have more frequently anti-cN1A antibodies, independently of the myositis subtype. They might develop systemic complications of SS. References:

[1] Felten R, Seror R, Vittecoq O, Hachulla E, Perdriger A, Dieude P, et al. SAT0470 Myositis, often suspected, is actually rare in primary Sjögren's syndrome: data from the French cohort ASSESS. In BMJ Publishing Group Ltd and European League Against Rheumatism; 2018. p. 1093.1-1093. Available from: http://ard.bmj.com/lookup/doi/10.1136/annrheumdis-2018-eular.2945

Disclosure of Interests: Dan LEVY: None declared, Benoit Nespola: None declared, Margherita Giannini: None declared, Renaud FELTEN: None declared, Coralie Varoquier: None declared, Marina Rinagel: None declared, Anne-Sophie Korganow: None declared, Vincent Poindron: None declared, Thierry Martin: None declared, Francois Maurier: None declared, Hassam Chereih: None declared, Bastien Bouldoires: None declared, Baptiste Hervier: None declared, Cédric Lenormand: None declared, Laurent Arnaud: None declared, Bernard Geny: None declared, Jean Sibilia: None declared, Jacques-Eric Gottenberg Grant/research support from: BMS, Pfizer, Consultant of: BMS, Sanofi-Genzyme, UCB, Speakers bureau: Abbvie, Eli Lilly and Co., Roche, Sanofi-Genzyme, UCB, alain meyer: None declared

DOI: 10.1136/annrheumdis-2020-eular.5766

\section{FRI0250 IDIOPATHIC INFLAMMATORY MYOPATHY DIAGNOSIS?" CLINICAL CORRELATION OF A COHORT OF PATIENTS POSITIVE FOR MYOSITIS ANTIBODIES}

J. Loarce-Martos ${ }^{1}$, C. Rita ${ }^{2}$, R. Ballester Gonzalez ${ }^{2}$, L. Calvo Sanz ${ }^{1}$, S. Garrote Corral' $^{1}$, A. García-Soidan², C. García-Hoz', I. Iturrieta-Zuazo², J. BachillerCorral' ${ }^{1}$, G. Roy ${ }^{2}{ }^{1}$ Ramón y Cajal University Hospital, Rheumatology Department, Madrid, Spain; ${ }^{2}$ Ramón y Cajal University Hospital, Immunology department, Madrid, Spain

Background: Idiopathic inflammatory myopathies (IIM) are a group of immune-mediated diseases characterized my muscle weakness, skin rash and systemic involvement. Myositis-specific antibodies (MSA) and myositis-associated antibodies (MAA) play a major role in IIM diagnosis, classification and prognosis. Nevertheless, MSA/MAA testing is not standardized and there very few studies addressing their relationship with other diseases.

Objectives: To describe a cohort of patients tested positive for MSA/MAA, and to explore it's relationship with IIM and other autoimmune diseases.

Methods: We retrospectively review all the serum samples obtained from patients tested for MSA/MAA during 2019 in the Immunology department of Ramón y Cajal University Hospital (Madrid, Spain). These antibodies were tested by specific immunoblot (EUROLINE: Autoimmune Inflammatory Myopathies $16 \mathrm{Ag}$ ) with highly purified MSA/MAA. Positivity was stablished according to absorbance titer and adjusted by positive control of each test (arbitrary units, AU). Patients were diagnosed with IIM according to their clinician diagnosis. Diagnosis and classification were confirmed by an independent rheumatologist (JL) according to current understanding of IIM classification.

Results: Three-hundred-seventy-five samples were tested for MSA during the study period. Two-hundred-seventy-nine were negative for all antibodies tested. Ninety-six samples were positive for one or more MSA/MAA, corresponding to 74 patients (11 patients had 2 different samples). Forty-nine $(66.2 \%)$ of the patients who tested positive were female and $25(33.8 \%)$ were male. Mean age was 58.65 years. Only 22 patients (29.7\%) had a confirmed diagnosis of IIM, 24 (32.4\%) had a diagnosis of other autoimmune disease, and 11 (14.9\%) were diagnosed with interstitial lung disease (ILD) (Figure 1). Six ILD patients had anti-PM-Scl or anti-Ku antibodies, which are associated with scleroderma or overlap-CTD myositis, nevertheless, they remained classified as ILD as no other features were described in this group.

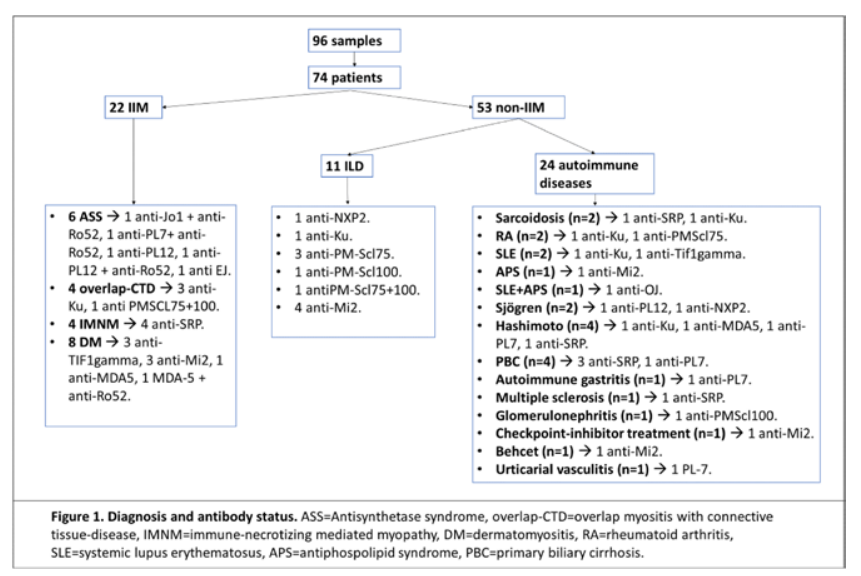

Seventeen patients were positive for more than 1 MAA or MSA, including 14 patients positive for anti Ro-52. Antibody titer was higher in the IIM group compared to non-myositis group (59.59 vs $44.16, \mathrm{p}=0.015)$. Anti Mi-2 was positive in 4 ILD without any other myositis features, and high titer anti-SRP ( $n=4$, mean $59.75 \mathrm{AU})$ was found in primary biliary cirrhosis (PBC) patients. Additionally, 5 patients positive for antiJo-1 using ELIA (Thermo Fisher) were diagnosed with antisynthetase syndrome. IIM diagnosis and its relationship with antibody titer is represented in table 1.

Table 1. Autoantibody titer according to diagnosis.

\begin{tabular}{|c|c|c|c|c|c|c|c|}
\hline $\begin{array}{l}\text { Antibody (Number } \\
\text { of patients) }\end{array}$ & $\begin{array}{l}\text { Number } \\
\text { of } \\
\text { samples }\end{array}$ & IIM & $\begin{array}{l}\text { IIM anti- } \\
\text { body titer } \\
\text { (AU) }\end{array}$ & Non-IIM & $\begin{array}{l}\text { Non-IIM } \\
\text { antibody } \\
\text { titer (AU) }\end{array}$ & $\begin{array}{l}\text { Other Al } \\
\text { diseases }\end{array}$ & $\begin{array}{c}\text { Anti } \\
\text { Ro-52 }\end{array}$ \\
\hline Anti Jo-1 (n=1) & 1 & $1(100 \%)$ & 92.7 & 0 & - & 0 & $1(100 \%)$ \\
\hline Anti PL-7 (n=8) & 11 & 3 (37.5\%) & 29.59 & $5(62.5 \%)$ & 25.59 & $5(62.5 \%)$ & $2(25 \%)$ \\
\hline Anti PL-12 ( $n=3)$ & 2 & $1(33.3 \%)$ & 53.95 & $2(66.6 \%)$ & 69.97 & $1(33.3 \%)$ & $2(50 \%)$ \\
\hline Anti EJ $(n=1)$ & 1 & $1(100 \%)$ & 99.46 & 0 & - & 0 & $1(100 \%)$ \\
\hline Anti OJ $(n=2)$ & 4 & 0 & - & $2(100 \%)$ & 23.04 & $1(50 \%)$ & 0 \\
\hline Anti Ku $(n=14)$ & 19 & $3(21.4 \%)$ & 107.25 & $11(78.6 \%)$ & 31.85 & $5(35.7 \%)$ & 0 \\
\hline $\begin{array}{l}\text { Anti Tif1 gamma } \\
\qquad(\mathrm{n}=5)\end{array}$ & 6 & $3(60 \%)$ & 40.12 & $2(40 \%)$ & 23.84 & $1(20 \%)$ & 0 \\
\hline Anti NXP2 (n=2) & 3 & 0 & - & $2(100 \%)$ & 13.99 & $1(50 \%)$ & $1(50 \%)$ \\
\hline Anti Mi2 $(n=12)$ & 17 & $3(25 \%)$ & 48.65 & $9(75 \%)$ & 26.67 & $4(33.3 \%)$ & 0 \\
\hline Anti SAE $(n=1)$ & 1 & 0 & - & $1(100 \%)$ & 18 & 0 & 0 \\
\hline Anti MDA5 $(n=2)$ & 3 & $2(100 \%)$ & 30.54 & 0 & & $1(50 \%)$ & $1(50 \%)$ \\
\hline Anti SRP $(n=9)$ & 12 & $4(44.4 \%)$ & 42.69 & $5(55.6 \%)$ & 68.16 & $5(55.5 \%)$ & $2(22.2 \%)$ \\
\hline $\begin{array}{l}\text { Anti PM-Scl75 and } \\
\text { PM-Scl100 }(n=2)\end{array}$ & 2 & $1(50 \%)$ & 68.6 & $1(50 \%)$ & 36.67 & 0 & 0 \\
\hline Anti PM-Scl75 $(\mathrm{n}=8)$ & 10 & 0 & 16.26 & $8(100 \%)$ & 22.72 & $3(37.5 \%)$ & $1(12.5 \%)$ \\
\hline $\begin{array}{l}\text { Anti PM-Scl100 } \\
\qquad(n=4)\end{array}$ & 5 & 0 & - & $4(100 \%)$ & 23.62 & $2(50 \%)$ & 0 \\
\hline
\end{tabular}

Conclusion: Only $28.7 \%$ of the patients that were MAA/MSA positive had a diagnosis of IIM. Other autoimmune diseases and ILD were commonly found in this group of MSA/MAA positive patients.

References:

[1] Damoiseaux J, Vulsteke JB, Tseng CW, Platteel ACM, Piette Y, Shovman O, et al. Autoantibodies in idiopathic inflammatory myopathies: Clinical associations and laboratory evaluation by mono- and multispecific immunoassays. Vol. 18, Autoimmunity Reviews. Elsevier B.V.; 2019. p. 293-305.

Disclosure of Interests: None declared

DOI: 10.1136/annrheumdis-2020-eular.5990

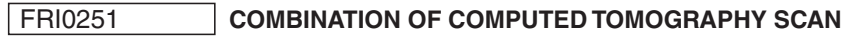 AND SERUM MYOSITIS SPECIFICIASSOCIATED AUTOANTIBODIES HELPS EARLY IDENTIFY AND TREAT PATIENTS WITH IPAF AND CTD-ILD}

S. Lyu ${ }^{1}$, H. C. Chen ${ }^{1}$, T. S. H. Lee ${ }^{2}$, Y. Li ${ }^{1}$, C. J. Cho ${ }^{1}$, F. C. Liu ${ }^{1}$, C. Y. Cheng ${ }^{1}$, S. J. Chu ${ }^{1}$, S. Y. Kuo ${ }^{1}$, D. M. Chang ${ }^{3}$, C. C. Lu ${ }^{1}{ }^{1}$ Tri-Service General Hospital, Taipei city, Taiwan, Republic of China; ${ }^{2}$ Taiwan Normal University, Taipei City, Taiwan, Republic of China; ${ }^{3}$ Taipei Veteran General Hospital, Taipei city, Taiwan, Republic of China

Background: Interstitial lung diseases (ILD) could originate from idiopathic cause or secondary to connective tissue diseases (CTD). The most common cause of CTD associated ILD (CTD-ILD) include mixed connective tissue disease, systemic sclerosis (SSc), inflammatory myositis such as polymyositis (PM) and dermatomyositis (DM). Our preliminary data had demonstrated that ILD is not uncommon in patients with rheumatoid arthritis (RA) and Sjogren's syndrome 